\title{
Erratum to: The role of activation-induced deaminase in antibody diversification and genomic instability
}

\author{
Jing H. Wang
}

Published online: 27 July 2013

(c) Springer Science+Business Media New York 2013

\section{Erratum to: Immunol Res (2013) 55:287-297 DOI 10.1007/s12026-012-8369-4}

Unfortunately, the incorrect References list was published in the original article though the references are cited correctly in the text.

The correct version of the References list is published below.

\section{References}

1. Ganesh K, Neuberger MS. The relationship between hypothesis and experiment in unveiling the mechanisms of antibody gene diversification. FASEB J. 2011;25:1123-32.

2. Jung D, Giallourakis C, Mostoslavsky R, Alt FW. Mechanism and control of $\mathrm{V}(\mathrm{D}) \mathrm{J}$ recombination at the immunoglobulin heavy chain locus. Annu Rev Immunol. 2006;24:541-70.

3. Muramatsu M, Kinoshita K, Fagarasan S, Yamada S, Shinkai Y, Honjo T. Class switch recombination and hypermutation require activation-induced cytidine deaminase (AID), a potential RNA editing enzyme. Cell. 2000;102:553-63.

4. Delker RK, Fugmann SD, Papavasiliou FN. A coming-of-age story: activation-induced cytidine deaminase turns 10. Nat Immunol. 2009;10:1147-53.

5. Kothapalli NR, Fugmann SD. Targeting of AID-mediated sequence diversification to immunoglobulin genes. Curr Opin Immunol. 2011;23:184-9.

The online version of the original article can be found under doi: $10.1007 / \mathrm{s} 12026-012-8369-4$.

\section{J. H. Wang ( $\bowtie)$}

Integrated Department of Immunology, University of Colorado School of Medicine and National Jewish Health, Denver, CO 80206, USA

e-mail: jing.wang@ucdenver.edu
6. Maul RW, Gearhart PJ. Controlling somatic hypermutation in immunoglobulin variable and switch regions. Immunol Res. 2010;47:113-22.

7. Pavri R, Nussenzweig MC. AID targeting in antibody diversity. Adv Immunol. 2011;110:1-26.

8. Stavnezer J. Complex regulation and function of activation-induced cytidine deaminase. Trends Immunol. 2011;32:194-201.

9. Storck S, Aoufouchi S, Weill JC, Reynaud CA. AID and partners: for better and (not) for worse. Curr Opin Immunol. 2011;23:337-44.

10. Dudley DD, Chaudhuri J, Bassing CH, Alt FW. Mechanism and control of $\mathrm{V}(\mathrm{D}) \mathrm{J}$ recombination versus class switch recombination: similarities and differences. Adv Immunol. 2005;86:43-112.

11. Fu YX, Chaplin DD. Development and maturation of secondary lymphoid tissues. Annu Rev Immunol. 1999;17:399-433.

12. Honjo T, Kinoshita K, Muramatsu M. Molecular mechanism of class switch recombination: linkage with somatic hypermutation. Annu Rev Immunol. 2002;20:165-96.

13. Di Noia JM, Neuberger MS. Molecular mechanisms of antibody somatic hypermutation. Annu Rev Biochem. 2007;76:1-22.

14. Longerich S, Basu U, Alt F, Storb U. AID in somatic hypermutation and class switch recombination. Curr Opin Immunol. 2006;18:164-74.

15. Nagaoka H, Muramatsu M, Yamamura N, Kinoshita K, Honjo T. Activation-induced deaminase (AID)-directed hypermutation in the immunoglobulin Smu region: implication of AID involvement in a common step of class switch recombination and somatic hypermutation. J Exp Med. 2002;195:529-34.

16. Chaudhuri J, Basu U, Zarrin A, Yan C, Franco S, Perlot T, et al. Evolution of the immunoglobulin heavy chain class switch recombination mechanism. Adv Immunol. 2007;94:157-214.

17. Stavnezer J, Guikema JE, Schrader CE. Mechanism and regulation of class switch recombination. Annu Rev Immunol. 2008;26:261-92.

18. Hackney JA, Misaghi S, Senger K, Garris C, Sun Y, Lorenzo $\mathrm{MN}$, et al. DNA targets of AID evolutionary link between antibody somatic hypermutation and class switch recombination. Adv Immunol. 2009;101:163-89.

19. Manis JP, Tian M, Alt FW. Mechanism and control of classswitch recombination. Trends Immunol. 2002;23:31-9.

20. Neuberger MS, Harris RS, Di Noia J, Petersen-Mahrt SK. Immunity through DNA deamination. Trends Biochem Sci. 2003;28:305-12. 
21. Neuberger MS, Rada C. Somatic hypermutation: activationinduced deaminase for $\mathrm{C} / \mathrm{G}$ followed by polymerase eta for $\mathrm{A} / \mathrm{T}$. J Exp Med. 2007;204:7-10.

22. Martomo SA, Yang WW, Gearhart PJ. A role for Msh6 but not Msh3 in somatic hypermutation and class switch recombination. J Exp Med. 2004;200:61-8.

23. Rada C, Ehrenstein MR, Neuberger MS, Milstein C. Hot spot focusing of somatic hypermutation in MSH2-deficient mice suggests two stages of mutational targeting. Immunity. 1998;9: 135-41.

24. Shen HM, Tanaka A, Bozek G, Nicolae D, Storb U. Somatic hypermutation and class switch recombination in Msh6(-/-) Ung(-/-) double-knockout mice. J Immunol. 2006;177: 5386-92.

25. Bardwell PD, Woo CJ, Wei K, Li Z, Martin A, Sack SZ, et al. Altered somatic hypermutation and reduced class-switch recombination in exonuclease 1-mutant mice. Nat Immunol. 2004;5:224-9.

26. Delbos F, De Smet A, Faili A, Aoufouchi S, Weill JC, Reynaud CA. Contribution of DNA polymerase eta to immunoglobulin gene hypermutation in the mouse. J Exp Med. 2005;201:1191-6.

27. Martomo SA, Yang WW, Wersto RP, Ohkumo T, Kondo Y, Yokoi $\mathrm{M}$, et al. Different mutation signatures in DNA polymerase eta- and MSH6-deficient mice suggest separate roles in antibody diversification. Proc Natl Acad Sci USA. 2005;102: 8656-61.

28. Zeng X, Winter DB, Kasmer C, Kraemer KH, Lehmann AR, Gearhart PJ. DNA polymerase eta is an A-T mutator in somatic hypermutation of immunoglobulin variable genes. Nat Immunol. 2001;2:537-41.

29. Franklin A, Blanden RV. A/T-targeted somatic hypermutation: critique of the mainstream model. Trends Biochem Sci. 2006; 31:252-8.

30. Matsuda T, Bebenek K, Masutani C, Hanaoka F, Kunkel TA. Low fidelity DNA synthesis by human DNA polymerase-eta. Nature. 2000;404:1011-3.

31. Matsuda T, Bebenek K, Masutani C, Rogozin IB, Hanaoka F, Kunkel TA. Error rate and specificity of human and murine DNA polymerase eta. J Mol Biol. 2001;312:335-46.

32. Rada C, Di Noia JM, Neuberger MS. Mismatch recognition and uracil excision provide complementary paths to both $\mathrm{Ig}$ switching and the A/T-focused phase of somatic mutation. Mol Cell. 2004;16:163-71.

33. Rada C, Williams GT, Nilsen H, Barnes DE, Lindahl T, Neuberger MS. Immunoglobulin isotype switching is inhibited and somatic hypermutation perturbed in UNG-deficient mice. Curr Biol. 2002;12:1748-55.

34. Jansen JG, Langerak P, Tsaalbi-Shtylik A, van den Berk P, Jacobs $\mathrm{H}$, de Wind N. Strand-biased defect in $\mathrm{C} / \mathrm{G}$ transversions in hypermutating immunoglobulin genes in Rev1-deficient mice. J Exp Med. 2006;203:319-23.

35. Ross AL, Sale JE. The catalytic activity of REV1 is employed during immunoglobulin gene diversification in DT40. Mol Immunol. 2006;43:1587-94.

36. Simpson LJ, Sale JE. Rev1 is essential for DNA damage tolerance and non-templated immunoglobulin gene mutation in a vertebrate cell line. EMBO J. 2003;22:1654-64.

37. Xue K, Rada C, Neuberger MS. The in vivo pattern of AID targeting to immunoglobulin switch regions deduced from mutation spectra in msh2-/- ung-/- mice. J Exp Med. 2006;203:2085-94.

38. Maul RW, Gearhart PJ. AID and somatic hypermutation. Adv Immunol. 2010;105:159-91.

39. Milstein C, Neuberger MS, Staden R. Both DNA strands of antibody genes are hypermutation targets. Proc Natl Acad Sci USA. 1998;95:8791-4.
40. Guikema JE, Linehan EK, Tsuchimoto D, Nakabeppu Y, Strauss PR, Stavnezer J, et al. APE1- and APE2-dependent DNA breaks in immunoglobulin class switch recombination. J Exp Med. 2007;204:3017-26.

41. Schrader CE, Guikema JE, Wu X, Stavnezer J. The roles of APE1, APE2, DNA polymerase beta and mismatch repair in creating $\mathrm{S}$ region DNA breaks during antibody class switch. Philos Trans R Soc Lond B Biol Sci. 2009;364:645-52.

42. Eccleston J, Schrader CE, Yuan K, Stavnezer J, Selsing E. Class switch recombination efficiency and junction microhomology patterns in Msh2-, Mlh1-, and Exo1-deficient mice depend on the presence of mu switch region tandem repeats. J Immunol. 2009; 183:1222-8.

43. Stavnezer J, Schrader CE. Mismatch repair converts AID-instigated nicks to double-strand breaks for antibody class-switch recombination. Trends Genet. 2006;22:23-8.

44. Sabouri Z, Okazaki IM, Shinkura R, Begum N, Nagaoka H, Tsuchimoto D, et al. Apex2 is required for efficient somatic hypermutation but not for class switch recombination of immunoglobulin genes. Int Immunol. 2009;21:947-55.

45. Dinkelmann M, Spehalski E, Stoneham T, Buis J, Wu Y, Sekiguchi JM, et al. Multiple functions of MRN in end-joining pathways during isotype class switching. Nat Struct Mol Biol. 2009;16:808-13.

46. Larson ED, Cummings WJ, Bednarski DW, Maizels N. MRE11/ RAD50 cleaves DNA in the AID/UNG-dependent pathway of immunoglobulin gene diversification. Mol Cell. 2005;20:367-75.

47. Rass E, Grabarz A, Plo I, Gautier J, Bertrand P, Lopez BS. Role of Mre11 in chromosomal nonhomologous end joining in mammalian cells. Nat Struct Mol Biol. 2009;16:819-24.

48. Zha S, Boboila C, Alt FW. Mre11: roles in DNA repair beyond homologous recombination. Nat Struct Mol Biol. 2009;16: 798-800.

49. Chaudhuri J, Alt FW. Class-switch recombination: interplay of transcription, DNA deamination and DNA repair. Nat Rev Immunol. 2004;4:541-52.

50. Tian M, Alt FW. Transcription-induced cleavage of immunoglobulin switch regions by nucleotide excision repair nucleases in vitro. J Biol Chem. 2000;275:24163-72.

51. Yu K, Chedin F, Hsieh CL, Wilson TE, Lieber MR. R-loops at immunoglobulin class switch regions in the chromosomes of stimulated B cells. Nat Immunol. 2003;4:442-51.

52. Khamlichi AA, Glaudet F, Oruc Z, Denis V, Le Bert M, Cogne M. Immunoglobulin class-switch recombination in mice devoid of any S mu tandem repeat. Blood. 2004;103:3828-36.

53. Luby TM, Schrader CE, Stavnezer J, Selsing E. The mu switch region tandem repeats are important, but not required, for antibody class switch recombination. J Exp Med. 2001;193:159-68.

54. Shinkura R, Tian M, Smith M, Chua K, Fujiwara Y, Alt FW. The influence of transcriptional orientation on endogenous switch region function. Nat Immunol. 2003;4:435-41.

55. Zarrin AA, Tian M, Wang J, Borjeson T, Alt FW. Influence of switch region length on immunoglobulin class switch recombination. Proc Natl Acad Sci USA. 2005;102:2466-70.

56. Zarrin AA, Alt FW, Chaudhuri J, Stokes N, Kaushal D, Du Pasquier L, et al. An evolutionarily conserved target motif for immunoglobulin class-switch recombination. Nat Immunol. 2004;5:1275-81.

57. Han L, Masani S, Yu K. Overlapping activation-induced cytidine deaminase hotspot motifs in Ig class-switch recombination. Proc Natl Acad Sci USA. 2011;108:11584-9.

58. Daniel JA, Santos MA, Wang Z, Zang C, Schwab KR, Jankovic M, et al. PTIP promotes chromatin changes critical for immunoglobulin class switch recombination. Science. 2010;329:917-23.

59. Jeevan-Raj BP, Robert I, Heyer V, Page A, Wang JH, Cammas $\mathrm{F}$, et al. Epigenetic tethering of AID to the donor switch region 
during immunoglobulin class switch recombination. J Exp Med. 2011;208:1649-60.

60. Stanlie A, Aida M, Muramatsu M, Honjo T, Begum NA. Histone3 lysine4 trimethylation regulated by the facilitates chromatin transcription complex is critical for DNA cleavage in class switch recombination. Proc Natl Acad Sci USA. 2010;107:22190-5.

61. Wang L, Wuerffel R, Feldman S, Khamlichi AA, Kenter AL. S region sequence, RNA polymerase II, and histone modifications create chromatin accessibility during class switch recombination. J Exp Med. 2009;206:1817-30.

62. Reinberg D, Sims RJ 3rd. de FACTo nucleosome dynamics. J Biol Chem. 2006;281:23297-301.

63. Belotserkovskaya R, Oh S, Bondarenko VA, Orphanides G, Studitsky VM, Reinberg D. FACT facilitates transcriptiondependent nucleosome alteration. Science. 2003;301:1090-3.

64. Rajagopal D, Maul RW, Ghosh A, Chakraborty T, Khamlichi AA, Sen R, et al. Immunoglobulin switch mu sequence causes RNA polymerase II accumulation and reduces dA hypermutation. J Exp Med. 2009;206:1237-44.

65. Basu U, Chaudhuri J, Alpert C, Dutt S, Ranganath S, Li G, et al. The AID antibody diversification enzyme is regulated by protein kinase A phosphorylation. Nature. 2005;438:508-11.

66. Chaudhuri J, Khuong C, Alt FW. Replication protein A interacts with AID to promote deamination of somatic hypermutation targets. Nature. 2004;430:992-8.

67. Cheng HL, Vuong BQ, Basu U, Franklin A, Schwer B, Astarita $\mathrm{J}$, et al. Integrity of the AID serine-38 phosphorylation site is critical for class switch recombination and somatic hypermutation in mice. Proc Natl Acad Sci U S A. 2009;106:2717-22.

68. Pavri R, Gazumyan A, Jankovic M, Di Virgilio M, Klein I, Ansarah-Sobrinho C, et al. Activation-induced cytidine deaminase targets DNA at sites of RNA polymerase II stalling by interaction with Spt5. Cell. 2010;143:122-33.

69. Nowak U, Matthews AJ, Zheng S, Chaudhuri J. The splicing regulator PTBP2 interacts with the cytidine deaminase AID and promotes binding of AID to switch-region DNA. Nat Immunol. 2011;12:160-6.

70. Xu Z, Fulop Z, Wu G, Pone EJ, Zhang J, Mai T, et al. 14-3-3 adaptor proteins recruit AID to $5^{\prime}$-AGCT- $3^{\prime}$-rich switch regions for class switch recombination. Nat Struct Mol Biol. 2010;17: 1124-35.

71. Basu U, Meng FL, Keim C, Grinstein V, Pefanis E, Eccleston J, et al. The RNA exosome targets the AID cytidine deaminase to both strands of transcribed duplex DNA substrates. Cell. 2011;144:353-63.

72. Yamane A, Resch W, Kuo N, Kuchen S, Li Z, Sun HW, et al. Deep-sequencing identification of the genomic targets of the cytidine deaminase AID and its cofactor RPA in B lymphocytes. Nat Immunol. 2011;12:62-9.

73. Faili A, Aoufouchi S, Gueranger Q, Zober C, Leon A, Bertocci $\mathrm{B}$, et al. AID-dependent somatic hypermutation occurs as a DNA single-strand event in the BL2 cell line. Nat Immunol. 2002;3:815-21.

74. Martin A, Bardwell PD, Woo CJ, Fan M, Shulman MJ, Scharff MD. Activation-induced cytidine deaminase turns on somatic hypermutation in hybridomas. Nature. 2002;415:802-6.

75. Sale JE, Neuberger MS. TdT-accessible breaks are scattered over the immunoglobulin $\mathrm{V}$ domain in a constitutively hypermutating B cell line. Immunity. 1998;9:859-69.

76. Wabl MR, Beck-Engeser GB, Burrows PD. Allelic inclusion in the pre-B-cell line 18-81. Proc Natl Acad Sci USA. 1984;81: 867-70.

77. Jacobs H, Bross L. Towards an understanding of somatic hypermutation. Curr Opin Immunol. 2001;13:208-18.
78. Odegard VH, Schatz DG. Targeting of somatic hypermutation. Nat Rev Immunol. 2006;6:573-83.

79. Liu M, Duke JL, Richter DJ, Vinuesa CG, Goodnow CC, Kleinstein $\mathrm{SH}$, et al. Two levels of protection for the B cell genome during somatic hypermutation. Nature. 2008;451: 841-5.

80. Pasqualucci L, Migliazza A, Fracchiolla N, William C, Neri A, Baldini L, et al. BCL-6 mutations in normal germinal center B cells: evidence of somatic hypermutation acting outside Ig loci. Proc Natl Acad Sci USA. 1998;95:11816-21.

81. Shen HM, Peters A, Baron B, Zhu X, Storb U. Mutation of BCL-6 gene in normal B cells by the process of somatic hypermutation of Ig genes. Science. 1998;280:1750-2.

82. Peng HZ, Du MQ, Koulis A, Aiello A, Dogan A, Pan LX, et al. Nonimmunoglobulin gene hypermutation in germinal center $\mathrm{B}$ cells. Blood. 1999;93:2167-72.

83. Storb U, Shen HM, Michael N, Kim N. Somatic hypermutation of immunoglobulin and non-immunoglobulin genes. Philos Trans R Soc Lond B Biol Sci. 2001;356:13-9.

84. Gordon MS, Kanegai CM, Doerr JR, Wall R. Somatic hypermutation of the B cell receptor genes B29 (Igbeta, CD79b) and mb1 (Igalpha, CD79a). Proc Natl Acad Sci USA. 2003;100: 4126-31.

85. Rogozin IB, Kolchanov NA. Somatic hypermutagenesis in immunoglobulin genes. II. Influence of neighbouring base sequences on mutagenesis. Biochim Biophys Acta. 1992;1171: $11-8$.

86. Rogozin IB, Pavlov YI, Bebenek K, Matsuda T, Kunkel TA. Somatic mutation hotspots correlate with DNA polymerase eta error spectrum. Nat Immunol. 2001;2:530-6.

87. Klotz EL, Hackett J Jr, Storb U. Somatic hypermutation of an artificial test substrate within an Ig kappa transgene. J Immunol. 1998;161:782-90.

88. Storb U, Klotz EL, Hackett J Jr, Kage K, Bozek G, Martin TE. A hypermutable insert in an immunoglobulin transgene contains hotspots of somatic mutation and sequences predicting highly stable structures in the RNA transcript. J Exp Med. 1998;188: 689-98.

89. Michael N, Martin TE, Nicolae D, Kim N, Padjen K, Zhan P, et al. Effects of sequence and structure on the hypermutability of immunoglobulin genes. Immunity. 2002;16:123-34.

90. Yelamos J, Klix N, Goyenechea B, Lozano F, Chui YL, Gonzalez Fernandez A, et al. Targeting of non-Ig sequences in place of the V segment by somatic hypermutation. Nature. 1995; 376:225-9.

91. Jolly CJ, Neuberger MS. Somatic hypermutation of immunoglobulin kappa transgenes: association of mutability with demethylation. Immunol Cell Biol. 2001;79:18-22.

92. Fukita Y, Jacobs H, Rajewsky K. Somatic hypermutation in the heavy chain locus correlates with transcription. Immunity. 1998; 9:105-14

93. Betz AG, Milstein C, Gonzalez-Fernandez A, Pannell R, Larson $\mathrm{T}$, Neuberger MS. Elements regulating somatic hypermutation of an immunoglobulin kappa gene: critical role for the intron enhancer/matrix attachment region. Cell. 1994;77:239-48.

94. Shen HM, Peters A, Kao D, Storb U. The 3' Igkappa enhancer contains RNA polymerase II promoters: implications for endogenous and transgenic kappa gene expression. Int Immunol. 2001;13:665-74.

95. Yang SY, Fugmann SD, Schatz DG. Control of gene conversion and somatic hypermutation by immunoglobulin promoter and enhancer sequences. J Exp Med. 2006;203:2919-28.

96. Inlay MA, Gao HH, Odegard VH, Lin T, Schatz DG, Xu Y. Roles of the Ig kappa light chain intronic and $3^{\prime}$ enhancers in Igk somatic hypermutation. J Immunol. 2006;177:1146-51. 
97. Perlot T, Alt FW, Bassing CH, Suh H, Pinaud E. Elucidation of $\mathrm{IgH}$ intronic enhancer functions via germ-line deletion. Proc Natl Acad Sci USA. 2005;102:14362-7.

98. Blagodatski A, Batrak V, Schmidl S, Schoetz U, Caldwell RB, Arakawa $\mathrm{H}$, et al. A cis-acting diversification activator both necessary and sufficient for AID-mediated hypermutation. PLoS Genet. 2009;5:e1000332.

99. Kothapalli N, Norton DD, Fugmann SD. Cutting edge: a cisacting DNA element targets AID-mediated sequence diversification to the chicken Ig light chain gene locus. J Immunol. 2008;180:2019-23.

100. Michael N, Shen HM, Longerich S, Kim N, Longacre A, Storb $\mathrm{U}$. The E box motif CAGGTG enhances somatic hypermutation without enhancing transcription. Immunity. 2003;19:235-42.

101. Tanaka A, Shen HM, Ratnam S, Kodgire P, Storb U. Attracting AID to targets of somatic hypermutation. J Exp Med. 2010;207: 405-15.

102. Schoetz U, Cervelli M, Wang YD, Fiedler P, Buerstedde JM. E2A expression stimulates Ig hypermutation. J Immunol. 2006; 177:395-400.

103. Maeda K, Singh SK, Eda K, Kitabatake M, Pham P, Goodman $\mathrm{MF}$, et al. GANP-mediated recruitment of activation-induced cytidine deaminase to cell nuclei and to immunoglobulin variable region DNA. J Biol Chem. 2010;285:23945-53.

104. Sakaguchi N, Maeda K, Kuwahara K. Molecular mechanism of immunoglobulin V-region diversification regulated by transcription and RNA metabolism in antigen-driven B cells. Scand J Immunol. 2011;73:520-6.

105. Kuwahara K, Fujimura S, Takahashi Y, Nakagata N, Takemori $\mathrm{T}$, Aizawa $\mathrm{S}$, et al. Germinal center-associated nuclear protein contributes to affinity maturation of B cell antigen receptor in T cell-dependent responses. Proc Natl Acad Sci USA. 2004;101: 1010-5.

106. Kuwahara K, Yoshida M, Kondo E, Sakata A, Watanabe Y, Abe E, et al. A novel nuclear phosphoprotein, GANP, is up-regulated in centrocytes of the germinal center and associated with MCM3, a protein essential for DNA replication. Blood. 2000; 95:2321-8.

107. Liu M, Schatz DG. Balancing AID and DNA repair during somatic hypermutation. Trends Immunol. 2009;30:173-81.

108. Celeste A, Difilippantonio S, Difilippantonio MJ, FernandezCapetillo O, Pilch DR, Sedelnikova OA, et al. H2AX haploinsufficiency modifies genomic stability and tumor susceptibility. Cell. 2003;114:371-83.

109. Rogakou EP, Pilch DR, Orr AH, Ivanova VS, Bonner WM. DNA double-stranded breaks induce histone H2AX phosphorylation on serine 139. J Biol Chem. 1998;273:5858-68.

110. Bassing $\mathrm{CH}$, Alt FW. H2AX may function as an anchor to hold broken chromosomal DNA ends in close proximity. Cell Cycle. 2004;3:149-53.

111. Franco S, Alt FW, Manis JP. Pathways that suppress programmed DNA breaks from progressing to chromosomal breaks and translocations. DNA Repair (Amst). 2006;5:1030-41.

112. Franco S, Gostissa M, Zha S, Lombard DB, Murphy MM, Zarrin $\mathrm{AA}$, et al. H2AX prevents DNA breaks from progressing to chromosome breaks and translocations. Mol Cell. 2006;21: 201-14.

113. Ramiro AR, Jankovic M, Callen E, Difilippantonio S, Chen HT, McBride KM, et al. Role of genomic instability and p53 in AIDinduced c-myc-Igh translocations. Nature. 2006;440:105-9.

114. Lieber MR. The mechanism of double-strand DNA break repair by the nonhomologous DNA end-joining pathway. Annu Rev Biochem. 2010;79:181-211.

115. Lieber MR, Gu J, Lu H, Shimazaki N, Tsai AG. Nonhomologous DNA end joining (NHEJ) and chromosomal translocations in humans. Subcell Biochem. 2010;50:279-96.
116. Rooney S, Chaudhuri J, Alt FW. The role of the non-homologous end-joining pathway in lymphocyte development. Immunol Rev. 2004;200:115-31.

117. Roth DB. Restraining the V(D)J recombinase. Nat Rev Immunol. 2003;3:656-66.

118. Yan CT, Boboila C, Souza EK, Franco S, Hickernell TR, Murphy $\mathrm{M}$, et al. IgH class switching and translocations use a robust nonclassical end-joining pathway. Nature. 2007;449:478-82.

119. Wang JH, Gostissa M, Yan CT, Goff P, Hickernell T, Hansen E, et al. Mechanisms promoting translocations in editing and switching peripheral B cells. Nature. 2009;460:231-6.

120. Boboila C, Yan C, Wesemann DR, Jankovic M, Wang JH, Manis J, et al. Alternative end-joining catalyzes class switch recombination in the absence of both $\mathrm{Ku} 70$ and DNA ligase 4 . J Exp Med. 2010;207:417-27.

121. Boboila C, Jankovic M, Yan CT, Wang JH, Wesemann DR, Zhang $\mathrm{T}$, et al. Alternative end-joining catalyzes robust $\mathrm{IgH}$ locus deletions and translocations in the combined absence of ligase 4 and Ku70. Proc Natl Acad Sci USA. 2010;107:3034-9.

122. Zhu C, Mills KD, Ferguson DO, Lee C, Manis J, Fleming J, et al. Unrepaired DNA breaks in p53-deficient cells lead to oncogenic gene amplification subsequent to translocations. Cell. 2002;109:811-21.

123. Wang JH, Alt FW, Gostissa M, Datta A, Murphy M, Alimzhanov $\mathrm{MB}$, et al. Oncogenic transformation in the absence of Xrcc4 targets peripheral B cells that have undergone editing and switching. J Exp Med. 2008;205:3079-90.

124. McVey M, Lee SE. MMEJ repair of double-strand breaks (director's cut): deleted sequences and alternative endings. Trends Genet. 2008;24:529-38.

125. Deriano L, Stracker TH, Baker A, Petrini JH, Roth DB. Roles for NBS1 in alternative nonhomologous end-joining of V(D)J recombination intermediates. Mol Cell. 2009;34:13-25.

126. Xie A, Kwok A, Scully R. Role of mammalian Mre11 in classical and alternative nonhomologous end joining. Nat Struct Mol Biol. 2009;16:814-8.

127. Lee-Theilen M, Matthews AJ, Kelly D, Zheng S, Chaudhuri J. CtIP promotes microhomology-mediated alternative end joining during class-switch recombination. Nat Struct Mol Biol. 2011;18:75-9.

128. Zhang Y, Jasin M. An essential role for CtIP in chromosomal translocation formation through an alternative end-joining pathway. Nat Struct Mol Biol. 2011;18:80-4.

129. Della-Maria J, Zhou Y, Tsai MS, Kuhnlein J, Carney JP, Paull TT, et al. Human Mre11/human Rad50/Nbs1 and DNA ligase IIIalpha/XRCC1 protein complexes act together in an alternative nonhomologous end joining pathway. J Biol Chem. 2011; 286:33845-53.

130. Saribasak H, Maul RW, Cao Z, McClure RL, Yang W, McNeill $\mathrm{DR}$, et al. XRCC1 suppresses somatic hypermutation and promotes alternative nonhomologous end joining in Igh genes. J Exp Med. 2011;208:2209-16.

131. Simsek D, Brunet E, Wong SY, Katyal S, Gao Y, McKinnon PJ, et al. DNA ligase III promotes alternative nonhomologous endjoining during chromosomal translocation formation. PLoS Genet. 2011;7:e1002080.

132. Stavnezer J, Bjorkman A, Du L, Cagigi A, Pan-Hammarstrom Q. Mapping of switch recombination junctions, a tool for studying DNA repair pathways during immunoglobulin class switching. Adv Immunol. 2010;108:45-109.

133. Caldecott KW. XRCC1 and DNA strand break repair. DNA Repair (Amst). 2003;2:955-69.

134. Boboila C, Oksenych V, Gostissa M, Wang JH, Zha S, Zhang Y, et al. Robust chromosomal DNA repair via alternative endjoining in the absence of X-ray repair cross-complementing protein 1 (XRCC1). Proc Natl Acad Sci USA. 2012;109:2473-8. 
135. Kuppers R. Mechanisms of B-cell lymphoma pathogenesis. Nat Rev Cancer. 2005;5:251-62.

136. Kuppers R, Dalla-Favera R. Mechanisms of chromosomal translocations in B cell lymphomas. Oncogene. 2001;20: 5580-94.

137. Ramiro AR, Jankovic M, Eisenreich T, Difilippantonio S, ChenKiang S, Muramatsu M, et al. AID is required for c-myc/ $\operatorname{IgH}$ chromosome translocations in vivo. Cell. 2004;118:431-8.

138. Ohno H. Pathogenetic and clinical implications of non-immunoglobulin; BCL6 translocations in B-cell non-Hodgkin's lymphoma. J Clin Exp Hematop. 2006;46:43-53.

139. Bertrand P, Bastard C, Maingonnat C, Jardin F, Maisonneuve C, Courel MN, et al. Mapping of MYC breakpoints in 8q24 rearrangements involving non-immunoglobulin partners in B-cell lymphomas. Leukemia. 2007;21:515-23.

140. Robbiani DF, Bothmer A, Callen E, Reina-San-Martin B, Dorsett $\mathrm{Y}$, Difilippantonio S, et al. AID is required for the chromosomal breaks in c-myc that lead to $\mathrm{c}-\mathrm{myc} / \mathrm{IgH}$ translocations. Cell. 2008;135:1028-38.

141. Robbiani DF, Bunting S, Feldhahn N, Bothmer A, Camps J, Deroubaix $\mathrm{S}$, et al. AID produces DNA double-strand breaks in non-Ig genes and mature B cell lymphomas with reciprocal chromosome translocations. Mol Cell. 2009;36:631-41.

142. Chiarle R, Zhang Y, Frock RL, Lewis SM, Molinie B, Ho YJ, et al. Genome-wide translocation sequencing reveals mechanisms of chromosome breaks and rearrangements in B Cells. Cell. 2011;147:107-19.

143. Klein IA, Resch W, Jankovic M, Oliveira T, Yamane A, Nakahashi $\mathrm{H}$, et al. Translocation-capture sequencing reveals the extent and nature of chromosomal rearrangements in B lymphocytes. Cell. 2011;147:95-106.

144. Staszewski O, Baker RE, Ucher AJ, Martier R, Stavnezer J, Guikema JE. Activation-induced cytidine deaminase induces reproducible DNA breaks at many non-Ig Loci in activated B cells. Mol Cell. 2011;41:232-42.

145. Muramatsu M, Sankaranand VS, Anant S, Sugai M, Kinoshita $\mathrm{K}$, Davidson NO, et al. Specific expression of activation-induced cytidine deaminase (AID), a novel member of the RNA-editing deaminase family in germinal center B cells. J Biol Chem. 1999;274:18470-6.

146. Gourzi P, Leonova T, Papavasiliou FN. A role for activationinduced cytidine deaminase in the host response against a transforming retrovirus. Immunity. 2006;24:779-86.

147. Szczylik C, Skorski T, Nicolaides NC, Manzella L, Malaguarnera L, Venturelli D, et al. Selective inhibition of leukemia cell proliferation by BCR-ABL antisense oligodeoxynucleotides. Science. 1991;253:562-5.

148. Van Etten RA, Jackson P, Baltimore D. The mouse type IV c-abl gene product is a nuclear protein, and activation of transforming ability is associated with cytoplasmic localization. Cell. 1989; 58:669-78.
149. Barila D, Superti-Furga G. An intramolecular SH3-domain interaction regulates c-Abl activity. Nat Genet. 1998;18:280-2.

150. Franz WM, Berger P, Wang JY. Deletion of an N-terminal regulatory domain of the $\mathrm{c}$-abl tyrosine kinase activates its oncogenic potential. EMBO J. 1989;8:137-47.

151. Jackson P, Baltimore D. N-terminal mutations activate the leukemogenic potential of the myristoylated form of c-abl. EMBO J. 1989;8:449-56.

152. Mayer BJ, Baltimore D. Mutagenic analysis of the roles of SH2 and $\mathrm{SH} 3$ domains in regulation of the Abl tyrosine kinase. Mol Cell Biol. 1994;14:2883-94.

153. Pendergast AM, Muller AJ, Havlik MH, Clark R, McCormick F, Witte ON. Evidence for regulation of the human ABL tyrosine kinase by a cellular inhibitor. Proc Natl Acad Sci USA. 1991;88:5927-31.

154. Quintas-Cardama A, Cortes J. Molecular biology of bcr-abl1positive chronic myeloid leukemia. Blood. 2009;113:1619-30.

155. Feldhahn N, Henke N, Melchior K, Duy C, Soh BN, Klein F, et al. Activation-induced cytidine deaminase acts as a mutator in BCR-ABL1-transformed acute lymphoblastic leukemia cells. J Exp Med. 2007;204:1157-66.

156. Klemm L, Duy C, Iacobucci I, Kuchen S, von Levetzow G, Feldhahn N, et al. The B cell mutator AID promotes B lymphoid blast crisis and drug resistance in chronic myeloid leukemia. Cancer Cell. 2009;16:232-45.

157. Gruber TA, Chang MS, Sposto R, Muschen M. Activationinduced cytidine deaminase accelerates clonal evolution in BCR-ABL1-driven B-cell lineage acute lymphoblastic leukemia. Cancer Res. 2010;70:7411-20.

158. Yoshikawa K, Okazaki IM, Eto T, Kinoshita K, Muramatsu M, Nagaoka $\mathrm{H}$, et al. AID enzyme-induced hypermutation in an actively transcribed gene in fibroblasts. Science. 2002;296: 2033-6.

159. Okazaki IM, Hiai H, Kakazu N, Yamada S, Muramatsu M, Kinoshita K, et al. Constitutive expression of AID leads to tumorigenesis. J Exp Med. 2003;197:1173-81.

160. Morris DS, Tomlins SA, Montie JE, Chinnaiyan AM. The discovery and application of gene fusions in prostate cancer. BJU Int. 2008;102:276-82.

161. Mano H. Non-solid oncogenes in solid tumors: EML4-ALK fusion genes in lung cancer. Cancer Sci. 2008;99:2349-55.

162. Lin C, Yang L, Tanasa B, Hutt K, Ju BG, Ohgi K, et al. Nuclear receptor-induced chromosomal proximity and DNA breaks underlie specific translocations in cancer. Cell. 2009;139:1069-83.

163. Matsumoto Y, Marusawa H, Kinoshita K, Endo Y, Kou T, Morisawa T, et al. Helicobacter pylori infection triggers aberrant expression of activation-induced cytidine deaminase in gastric epithelium. Nat Med. 2007;13:470-6. 